\title{
Reactive oxygen species regulate urokinase plasminogen activator expression and cell invasion via mitogen-activated protein kinase pathways after treatment with hepatocyte growth factor in stomach cancer cells
}

\author{
Kyung Hee Lee ${ }^{1}$, Sang Woon Kim² and Jae-Ryong Kim*3,4
}

Address: ${ }^{1}$ Department of Hematology-Oncology, College of Medicine, Yeungnam University, Daegu, Korea, ${ }^{2}$ Surgery, College of Medicine, Yeungnam University, Daegu, Korea, ${ }^{3}$ Biochemistry and Molecular Biology, College of Medicine, Yeungnam University, Daegu, Korea and ${ }^{4}$ AgingAssociated Vascular Disease Research Center, College of Medicine, Yeungnam University, Daegu, Korea

Email: Kyung Hee Lee - lkhee@med.yu.ac.kr; Sang Woon Kim - swkim@med.yu.ac.kr; Jae-Ryong Kim* - kimjr@med.yu.ac.kr

* Corresponding author

Published: 4 June 2009

Journal of Experimental \& Clinical Cancer Research 2009, 28:73 doi:10.1 186/1756-9966-28-73

This article is available from: http://www.jeccr.com/content/28/1/73

(C) 2009 Lee et al; licensee BioMed Central Ltd.

This is an Open Access article distributed under the terms of the Creative Commons Attribution License (http://creativecommons.org/licenses/by/2.0), which permits unrestricted use, distribution, and reproduction in any medium, provided the original work is properly cited.
Received: 3 February 2009
Accepted: 4 June 2009

\begin{abstract}
Background: Reactive oxygen species (ROS) are closely associated with the intracellular signal cascade, thus strongly implicating involvement in tumor progression. However, the mechanism by which ROS are generated and how ROS target downstream molecules to trigger tumor metastasis is unclear. In this study, we investigated the underlying signal pathways in ROS-induced urokinase plasminogen activator (uPA) expression in the human gastric cancer cells, NUGC-3 and MKN-28.

Methods and Results: Intracellular ROS, as determined using the fluorescent probe, 2'-7' dichlorofluorescein diacetate, decreased after treatment with hepatocyte growth factor (HGF). We confirmed that Rac-I regulated ROS production after activation of the AKT pathway with HGF. Exogenously added $\mathrm{H}_{2} \mathrm{O}_{2}$ promoted the expression of $\mathrm{HGF}$, but not in a dose-dependent manner and also showed negative expression of HGF after co-treatment with $\mathrm{H}_{2} \mathrm{O}_{2}$ and HGF. Treatment with NAC, an intracellular free radical scavenger, decreased the enhancement of uPA production and tumor invasion in both cells. We clarified the downstream pathways regulated by ROS after treatment with $\mathrm{H}_{2} \mathrm{O}_{2}$, which showed negative control between FRK and p38 kinase activities for uPA regulation.
\end{abstract}

Conclusion: HGF regulates Rac-I-induced ROS production through the Akt pathway and ROS regulates uPA production and invasion via MAP kinase, which provides novel insight into the mechanisms underlying the progression of gastric cancer.

\section{Background}

Gastric cancer is the second most common cause of cancer death worldwide despite of the improved prognosis. To understand the precise mechanisms underlying invasion and metastasis would be helpful in improving survival. ROS, such as superoxide anion $\left(\mathrm{O}_{2}^{-}\right)$, hydrogen peroxide
$\left(\mathrm{H}_{2} \mathrm{O}_{2}\right)$, and hydroxyl radical ( $\left.\mathrm{HO}^{-}\right)$, have emerged as highly toxic agents responsible for a wide variety of tissue damage [1] The involvement of these ROS in the pathogenesis of gastric diseases first became evident from the study of gastric mucosal injuries under normal conditions. ROS are relatively harmless, but when produced 
excessively or during deficient antioxidant defense, the oxidant and antioxidant balance is disturbed and the metabolites become toxic, which may lead to the initiation and promotion of cancer [2]. However, despite the positive correlation between the increased generation of ROS and the invasion of cancer, the specific mechanisms by which antioxidants act to suppress cancer development through ROS is unknown.

HGF has multiple biologic effects on a wide variety of cells, including mitogenic, motogenic, morphogenic, and anti-apoptotic activities $[3,4]$. The receptor for HGF is cMet, a proto-oncogene product. Overexpression and mutation of the c-Met receptor has been well-described in various cancers $[5,6]$. Some studies have reported that HFG stimulates the migration and invasiveness of transformed epithelial cells concomitantly with the up-regulation of uPA [7]. In a separate study, HGF/c-Met signaling enhanced gastric cancer cell proliferation and increased uPA synthesis and activity. Inhibition of uPA receptors by monoclonal antibody against the uPA receptor decreased tumor cell invasion. Mitogen-activated protein kinase (MAPK) transduces extracellular signals into cellular responses, and thus plays an important role in proliferation, apoptosis, differentiation, and migration $[8,9]$. Gupta et al. [10] reported that increased ROS levels enhance MAP kinase activity for malignant progression of mouse keratinocyte cell lines.

In this study, we found that HGF modulates Rac-1-regulated ROS production, ROS induces the expression of uPA via the MAPK pathway, and stimulates the invasiveness of human gastric cancer cells.

\section{Methods \\ Cell cultures}

Two human gastric cancer cell lines (a poorly differentiated adenocarcinoma [NUGC-3] and a moderately differentiated tubular adenocarcinoma [MKN-28]), which were obtained from the Korea Cell Line Bank (Seoul, Korea), were used in the experiments described herein. Cells were maintained in Dulbecco's modified Eagle's medium (DMEM) supplemented with 10\% fetal bovine serum, 1 $\mathrm{mM}$ sodium pyruvate, $0.1 \mathrm{mM}$ non-essential amino acids, $2 \mathrm{mM}$ L-glutamine, a 2-fold vitamin solution, and $50 \mathrm{U} /$ $\mathrm{ml}$ penicillin/streptomycin (Life Technologies, Inc., Gaithersburg, MD, USA) in an incubator under a humidified atmosphere of $5 \% \mathrm{CO}_{2}$ and $95 \%$ air at $37^{\circ} \mathrm{C}$. Unless otherwise noted, cells were passaged and removed at $70 \%$ to $80 \%$ confluency.

\section{Reagents and antibodies}

Antibodies against ERK, p38, phospho-ERK, and phospho-p38 were purchased from Cell Signaling Technology (Beverly, Massachusetts, USA). Antibodies against AKT, phosphor-AKT, and Rac1 were obtained from Santa Cruz
Biotechnology, Inc. (Santa Cruz, California, USA). N-acetylcysteine (NAC), hydrogen peroxide $\left(\mathrm{H}_{2} \mathrm{O}_{2}\right)$, and $\mathrm{LY}$ 294002 were purchased from Sigma (St. Louis, Missouri, USA). 2'-7'-dichlorofluorescin diacetate (DCF-DA) was obtained from Molecular Probes (Eugene, Oregon, USA). Horseradish peroxidase-conjugated anti-mouse and antirabbit antibodies were purchased from Bio-Rad Laboratories (Philadelphia, Pennsylvania, USA). Recombinant human HGF (R\&D Systems, Inc, Minneapolis, Minnesota, USA) and human uPA antibody (389; American Diagnostica, Greenwich, Connecticut, USA) were also purchased. A dominant positive Rac-1 (Q61L) plasmid was kindly provided by Dr. K. Hahn of the university of North Carolina.

\section{Real-time PCR}

Complementary DNA (cDNA) was synthesized from total RNA using MMLV reverse transcriptase (Promega Corp., Madison, Wisconsin, USA) by the oligo (dT) priming method in a $10 \mu \mathrm{l}$ reaction mixture. Real-time PCR analysis was performed using a lightCycler1.5 Instrument (Roche, Mannheim, Germany). PCR was performed in a LightCycler capillary in a $10 \mu \mathrm{l}$ reaction volume that contained 1* DNA Master SYBR Green I, $2.5 \mathrm{mM} \mathrm{MgCI}_{2}, 1 \mu \mathrm{l}$ cDNA, and $0.4 \mathrm{uM}$ primers. The PCR protocol was as follows: initial denaturation for 2 minutes at $95^{\circ} \mathrm{C}, 45$ cycles at $95^{\circ} \mathrm{C}$ for 10 seconds, $60^{\circ} \mathrm{C}$ for 5 seconds, and $72^{\circ} \mathrm{C}$ for 12 seconds. Results were analyzed with LightCycler Software, version 3.5.3. Sequence-specific primers for HGF were a forward primer, gggctgaaaagattggatca and a reverse primer, ttgtattggtgggtgcttca.

\section{Western blot analysis}

Cells were harvested and incubated with a lysis buffer (50 $\mathrm{mM}$ Tris-HCl [pH 8.0], $150 \mathrm{mM} \mathrm{NaCl}, 1 \mathrm{mM}$ EDTA, $1 \%$ Trion X-100, 10\% glycerol, $1 \mathrm{mM} \mathrm{PMSF}, 1 \mathrm{mM}$ sodium vanadate, and $5 \mathrm{mM} \mathrm{NaF}$ ) with protease inhibitors and centrifuged at $15,000 \mathrm{rpm}$ at $4{ }^{\circ} \mathrm{C}$ for $10 \mathrm{~min}$. Proteins (50 $\mu \mathrm{g}$ ) were separated on $10 \%$ SDS-polyacrylamide gels and transferred to nitrocellulose membranes. The membranes were soaked with $5 \%$ non-fat dried milk in $10 \mathrm{mM}$ Tris$\mathrm{HCl}(\mathrm{pH} 7.5), 150 \mathrm{mM} \mathrm{NaCl}$, and $0.05 \%$ Tween-20 (TTBS) for $30 \mathrm{~min}$ and then incubated overnight with a primary antibody at $4{ }^{\circ} \mathrm{C}$. After washing 6 times with TTBS for $5 \mathrm{~min}$, the membranes were incubated with a horseradish peroxidase-conjugated secondary antibody for 90 $\min$ at $4^{\circ} \mathrm{C}$. The membranes were rinsed 3 times with TTBS for $30 \mathrm{~min}$ and the antigen-antibody complex was detected using the enhanced chemiluminescence detection system.

\section{Measurement of Rac-I activity}

Rac-1 activity was measured using the Rac- 1 activation kit (Upstate Biotechnology, New York, USA). Briefly, wholeprotein extracts were immunoprecipitated with the protein binding domain of PAK-1 PBD. PAK-1 PBD only 
binds to activated forms of Rac- 1 and cdc42. Immunoprecipitated proteins were separated in SDS-polyacrylamide gels and blotted with anti-Racl.

\section{Measurement of ROS}

ROS production was measured using the DCF-DA assay. In brief, cells were seeded in $60 \mathrm{~mm}$ culture dishes at 70\% confluence and then starved in DMEM for $24 \mathrm{~h}$. The cells were treated with $\operatorname{HGF}(0,10$, or $40 \mathrm{ng} / \mathrm{ml})$. After treatment with HGF, cells were incubated with $10 \mu \mathrm{M}$ of DCFDA for $10 \mathrm{~min}$. The cells were harvested, washed once, and resuspended in PBS. Fluorescence was monitored using a flow cytometer (Becton-Dickinson, San Jose, California, USA). The mean of the DCF fluorescence intensity was obtained from 10000 cells using $480 \mathrm{~nm}$ excitation and $540 \mathrm{~nm}$ emission settings. By using the same settings, the fluorescent intensity was obtained from each experimental group. Fluorescent levels were expressed as the percentage increase over the control.

\section{Standard two chamber invasion assay}

Cells $\left(1 \times 10^{4}\right)$ and NAC $(5 \mathrm{mM})$ were placed in the upper chamber of a matrigel migration chamber with 0.8micron pores (Fisher Scientific, Houston, TX, USA). Media containing 5\% FBS and HGF (0 or $10 \mathrm{ng} / \mathrm{mL})$, with or without NAC ( $5 \mathrm{mM})$, was added to the bottom chamber. After incubation for 48 hours, the cells were fixed and stained using a HEMA 3 stain set (Curtis Matheson Scientific, Houston, Texas, USA) according to the manufacturer's instruction. The stained filter membrane was cut and placed on a glass slide. The migrated cells were counted under light microscopy (10 fields at $200 \times$ power).

\section{Statistical analysis}

The results of three independent experiments were expressed as the means \pm SD and were analyzed by Student's $t$-test.

\section{Results}

HGF suppresses ROS generation in c-Met-overexpressing gastric cancer cells

The intracellular ROS levels in c-Met-overexpressing NUGC-3 and MKN-28 cells treated with HGF were determined using DCF-DA by flow cytometry. Stimulation of cMet-overexpressing gastric cancer cells with HGF significantly reduced the basal level of ROS in a dose-dependent manner (Figure 1).

\section{HGF suppresses Rac- I-regulated ROS production through activation of Akt}

We examined the role of HGF in modulating ROS production, particularly as regulated by Rac- 1 . Treatment with HGF suppressed the basal activity of Rac- 1 and increased Rac- 1 activity induced by $\mathrm{H}_{2} \mathrm{O}_{2}$ treatment (Figure 2A). In addition, treatment with HGF suppressed also the Rac-1
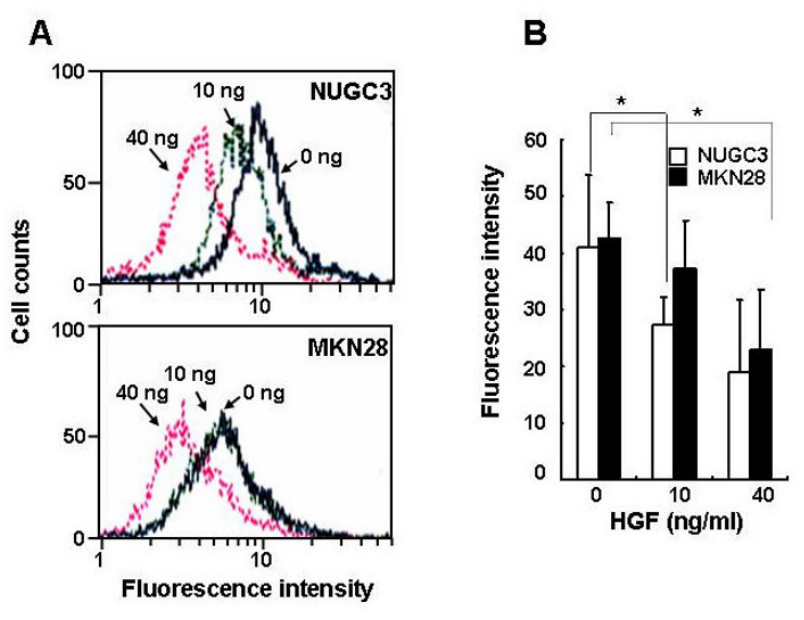

\section{Figure I}

Effects of HGF on ROS accumulation. Serum-starved cells were treated with increasing concentrations of $\operatorname{HGF}(0$, 10 , and $40 \mathrm{ng} / \mathrm{ml})$. After incubation for I h, the cells were incubated with DCF-DA (10 $\mu \mathrm{M})$ for $10 \mathrm{~min}$. The cells were washed with PBS, trypsinized, and resuspended in PBS. The intensity of DCF-fluorescence was immediately measured with a flow cytometer (A). Mean fluorescence intensity was obtained from 3 independent experiments and plotted (B). Representative data from 3 independent experiments were shown. Values are the means \pm SD of three independent experiments. Statistical significance was estimated by Student's $t$-test $(*, p<0.05)$.

activity increased in Rac-1 dominant positive cells (Figure 2B). Pretreatment of cells with LY 294002, a PI3-kinase inhibitor, activated Rac-1 (Figure 3). Next, we examined whether Akt is involved in the reduction of the ROS level induced by HGF. Treatment of NUGC-3 and MKN-28 cells with HGF caused Akt activation in a dose-dependent manner (Figure 4A) and pre-incubation of cells with $\mathrm{LY}$ 294002 reduced HGF-induced Akt phosphorylation (Figure 4B). Furthermore, inhibition of Akt by LY 294002 treatment increased the ROS levels. More importantly, the effect of LY 294002 was abolished by HGF, as determined using DCF-DA by flow cytometry (Figure 5). These results suggest that PI3-kinase is an essential mediator through which HGF inhibits ROS generation.

\section{Upregulation of HGF mRNA levels in gastric cancer cell lines treated with $\mathrm{H}_{2} \mathrm{O}_{2}$}

To understand the mechanism of uPA production of ROS, we examined HGF gene expression using the RT-PCR method. The levels of HGF mRNA were 1.7-2.4 fold higher in cells treated with $100 \mu \mathrm{M} \mathrm{H}_{2} \mathrm{O}_{2}$ than in untreated cells. However, HGF mRNA levels were decreased when treated with $500 \mu \mathrm{M} \mathrm{H}_{2} \mathrm{O}_{2}$ (Figure 6). This might be due to $\mathrm{H}_{2} \mathrm{O}_{2}$ cytotoxicity. Subsequently, we measured HGF mRNA levels from both cell lines in the absence or presence of exogenous HGF and/or $\mathrm{H}_{2} \mathrm{O}_{2}$. The 
A

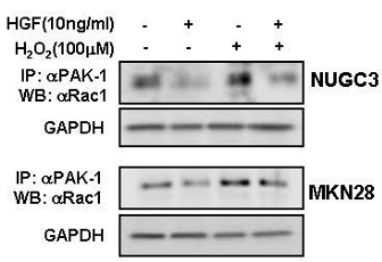

B

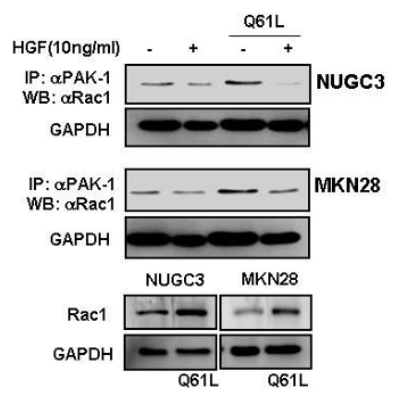

Figure 2

Effects of HGF and $\mathrm{H}_{2} \mathrm{O}_{2} / L Y 294002$ on Rac-I activation. Serum-starved cells was pretreated with or without $\mathrm{H}_{2} \mathrm{O}_{2}(100 \mu \mathrm{M})$ for 30 min and then treated with or without $10 \mathrm{ng} / \mathrm{ml}$ HGF (A). Rac-I dominant positive cells (Q6IL) were treated with or without HGF (B). After incubation for $15 \mathrm{~min}$, the cells were collected, washed, and then sonicated. Cell lysates were immunoprecipitated with PAK-I PBD and Rac-I activation was measured by Western blotting with a Rac-I antibody. Representative data from three independent experiments were shown.

levels of HGF mRNA were suppressed by exogenous treatment of $\mathrm{HGF}$ and $\mathrm{H}_{2} \mathrm{O}_{2}$ (Figure 7).

\section{Effect of $\mathrm{H}_{2} \mathrm{O}_{2}$ and NAC on uPA production}

uPA gradually accumulated in both cell lines after treatment with HGF. Treatment with $\mathrm{H}_{2} \mathrm{O}_{2}$ resulted in an increase in the uPA protein level in both cell lines. When we treated cells with $\mathrm{H}_{2} \mathrm{O}_{2}$ and HGF, the uPA protein level

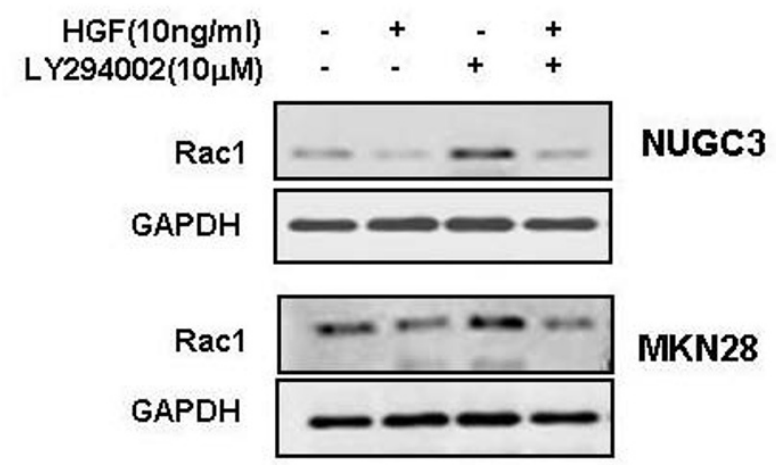

Figure 3

Effects of HGF and LY 294002 on Rac-I activation. Serum-starved cells was pretreated with or without LY (I0 $\mu \mathrm{M})$ for 30 min and then treated with or without HGF. After incubation for $15 \mathrm{~min}$, the cells were collected, washed, and then sonicated. Cell lysates were immunoprecipitated with PAK-I PBD and Rac-I activation was measured by Western blotting with a Rac-I antibody. Representative data from three independent experiments were shown.

A

$\mathbf{B}$

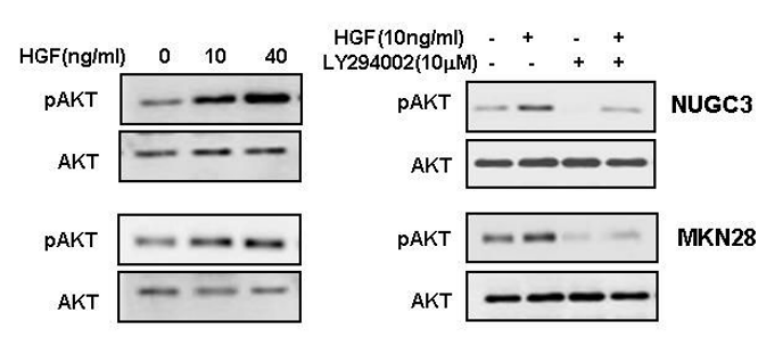

Figure 4

Effects of HGF or LY 294002 on Akt phosphorylation. Serum-starved cells were treated with increasing concentrations of HGF for $15 \mathrm{~min}$. The protein levels of Akt and phospho-Akt were measured by Western blot analysis (A).

Serum-starved cells were pretreated with LY 294002 ( 10 $\mu \mathrm{M})$ for $30 \mathrm{~min}$ and then treated with HGF $(10 \mathrm{ng} / \mathrm{ml})$. After incubation for $15 \mathrm{~min}$, the protein levels of Akt and phosphoAkt were determined by Western blot analysis (B). Representative data from three independent experiments are shown.

was decreased. To investigate the effect of $\mathrm{N}$-acetylcysteine (NAC), a precursor of glutathione and an intracellular free radical scavenger, on HGF-induced uPA production, we treated both cell lines with NAC. NAC decreased the HGFinduced uPA production (Figure 8).
A

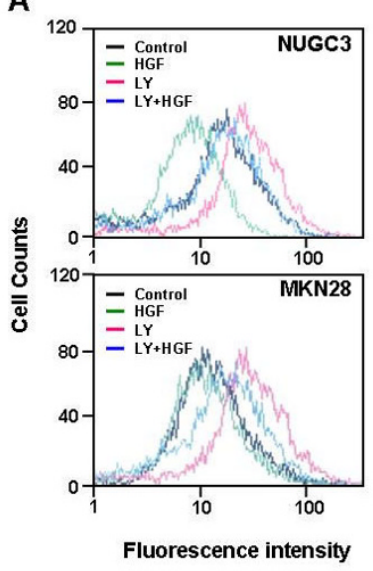

B

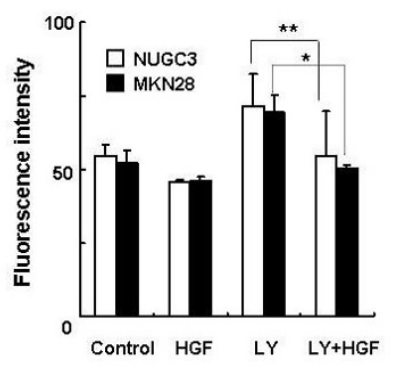

\section{Figure 5}

Effects of LY 294002 on ROS accumulation. Serumstarved cells were pretreated with LY $294002(10 \mu \mathrm{M})$ for 30 min and then treated with HGF $(10 \mathrm{ng} / \mathrm{ml})$. The intensity of DCF fluorescence was measured with flow cytometry (A). Mean fluorescence intensity was obtained from 3 independent experiments and plotted (B). Representative data from three independent experiments are shown. Values are the means \pm SD of three independent experiments. Statistical significance was estimated by Student's $t$-test $(*, p<0.05$; **; $p<0.01$ ). 


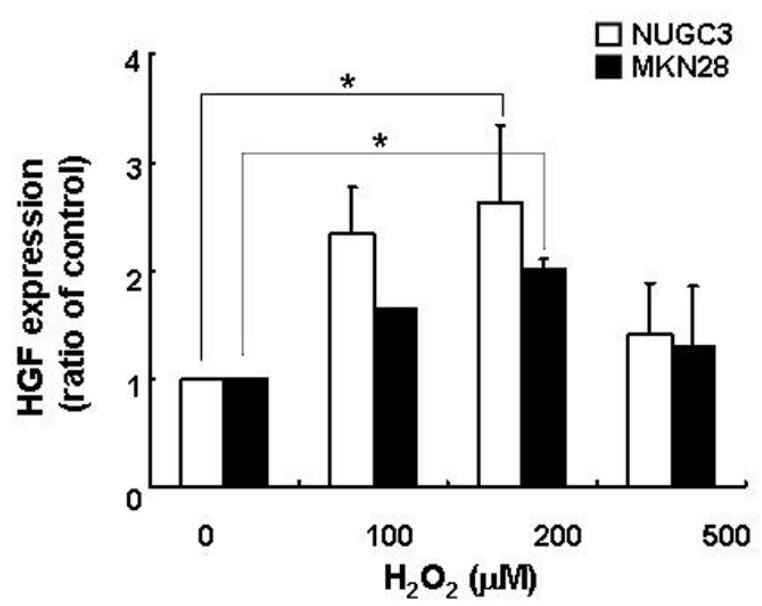

Figure 6

Effects of $\mathrm{H}_{2} \mathrm{O}_{2}$ on the levels of HGF mRNA. Cells were serum-starved and treated with increasing concentrations of $\mathrm{H}_{2} \mathrm{O}_{2}(0,100,200$, and $500 \mu \mathrm{M})$. The expression level of HGF was measured by real-time RT-PCR. Values are the means \pm SD of three independent experiments.

\section{Effects of NAC on cell invasion}

To examine the effects of HGF/c-Met-mediated uPA induction on the invasive properties of tumor cell phenotypes, we performed an in vitro invasion assay using a matrigal migration chamber. The invasiveness of HGFtreated cells was 2.7-fold higher in NUGC-3 cells, and 1.8-

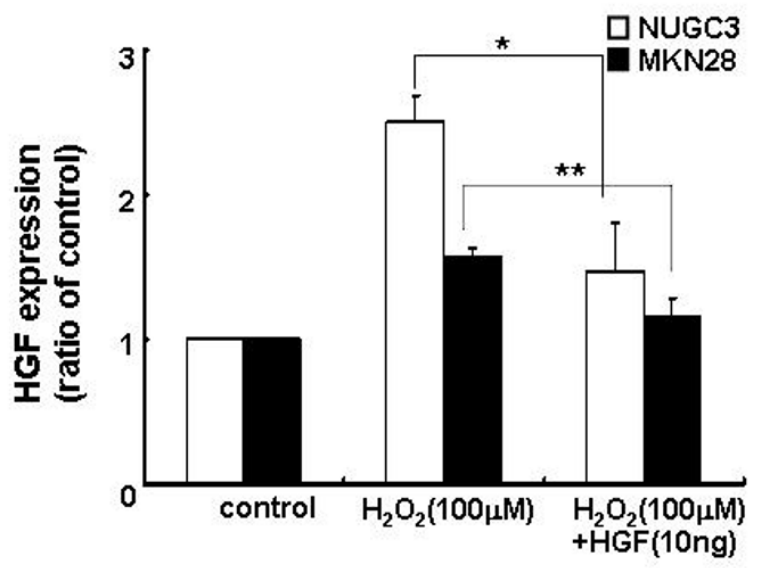

Figure 7

Level of expression of HGF after treatment with $\mathbf{H}_{2} \mathrm{O}_{2}$ and/or HGF. Cells were serum-starved and treated with $\mathrm{H}_{2} \mathrm{O}_{2}(\mathrm{I} 00 \mu \mathrm{M})$ and/or $\mathrm{HGF}(10 \mathrm{ng} / \mathrm{ml})$. The level of HGF mRNA was measured by real-time RT-PCR analysis. Values are the means \pm SD of triplicates of three independent experiments. Statistical significance was estimated by Student's $t$-test $(*, p<0.05 ; * *, p<0.01)$. fold higher in the MKN-28 cells than in the untreated cells. We hypothesized that HGF-mediated uPA upregulation is responsible for the invasive properties of tumor cell phenotypes, and consequently blocking uPA activity could be a potential target in inhibiting tumor cell invasion. To test this hypothesis, we studied the effects of NAC on tumor cell invasiveness, and showed that invasiveness of NAC- treated cells was $50 \%$ lower in NUGC-3 cells and $90 \%$ lower in the MKN-28 cells than in the untreated cells. When we co-treated with exogenous HGF and NAC, cell invasion was also decreased. The fact that the invasive properties of these cells can be inhibited by NAC suggests that the regulation of ROS may be useful for a therapeutic target to halt metastasis in stomach cancers (Figure 9).

Effect of $\mathrm{H}_{2} \mathrm{O}_{2}$ on ERK and p38 activation induced by HGF To demonstrate the effect of $\mathrm{H}_{2} \mathrm{O}_{2}$ on HGF-mediated ERK and p38 activation, we treated both cells with $\mathrm{H}_{2} \mathrm{O}_{2}$. Treatment with $\mathrm{H}_{2} \mathrm{O}_{2}$ increased the activity of ERK and p38. When cells were treated with $\mathrm{H}_{2} \mathrm{O}_{2}$ and HGF together, the activation of ERK and p38 kinase was decreased (Figure $10)$.

\section{Effect of ERK and p38 inhibitor on $\mathrm{H}_{2} \mathrm{O}_{2}$-induced uPA expression}

To test whether ERK and p38 activation was involved in $\mathrm{H}_{2} \mathrm{O}_{2}$-mediated uPA secretion, cells were pretreated with PD 098059 or SB 203580, and uPA secretion was measured by Western blotting. Both cells showed that $\mathrm{H}_{2} \mathrm{O}_{2}$ mediated uPA secretion was reduced with increasing concentrations of PD 098059. Densitometric analysis indicated that $10 \mu \mathrm{M}$ PD 098059 reduced the urokinase secretion $>50 \%$. In contrast, pretreatment with SB 203580 increased uPA secretion. These results suggested that $\mathrm{H}_{2} \mathrm{O}_{2}$-mediated uPA secretion and the augmentation of this activity was regulated by ERK and p38 activation (Figure 11).

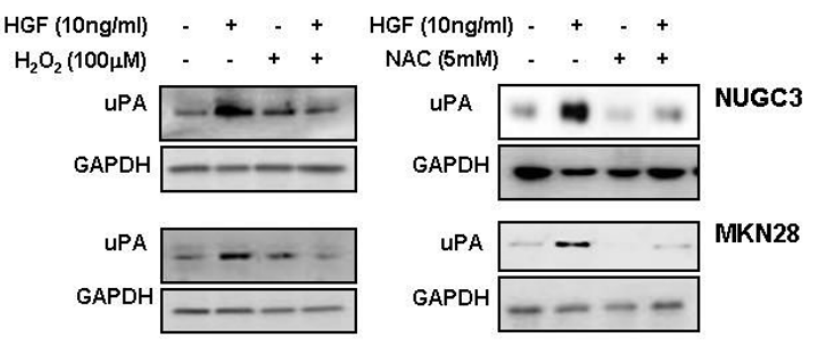

Figure 8

Effects of $\mathrm{H}_{2} \mathrm{O}_{2}$ and NAC on HGF-mediated upregulation of uPA. Serum-starved cells were pretreated with or without $\mathrm{H}_{2} \mathrm{O}_{2}(100 \mu \mathrm{M})$ and $\mathrm{NAC}(5 \mathrm{mM})$ for $30 \mathrm{~min}$, and then treated with or without HGF $(10 \mathrm{ng} / \mathrm{ml})$. After incubation for $24 \mathrm{~h}$, uPA secreted in culture media was measured by Western blot analysis with a uPA antibody. Representative data from 3 independent experiments were shown. 


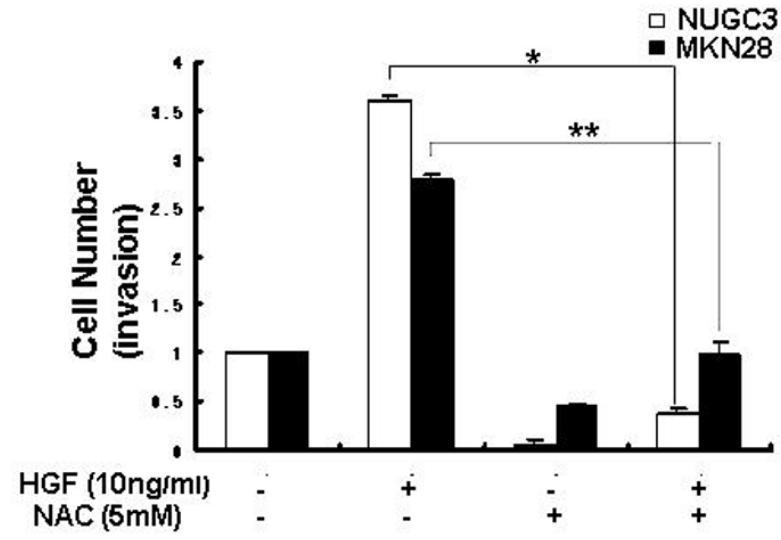

Figure 9

Effects of NAC on in vitro invasiveness. Cells in RPMI 1640 media supplemented with 5\% FBS were placed in the upper chamber of Matrigel chamber and treated with or without NAC. The bottom chamber was filled with media containing 5\% FBS and HGF with or without NAC. After 48 $h$ of incubation, the cells which migrated through the filter were counted under light microscopy ( 10 fields at 200x power). Values are the means \pm SD of triplicates of three independent experiments. Statistical significance was estimated by Student's t-test $\left(*, P<0.05 ;{ }^{* *}, p<0.0 \mathrm{I}\right)$.

\section{Effects of PD 098059 andlor SB 203580 on $\mathrm{H}_{2} \mathrm{O}_{2}$-induced} ERKI/2 phosphorylation

To investigate the possibility of an interaction between ERK and p38 activation in $\mathrm{H}_{2} \mathrm{O}_{2}$-mediated uPA expression, the effect of SB 203580 on ERK activation was measured. Pretreatment with SB 203580 increased ERK phosphorylation in the $\mathrm{H}_{2} \mathrm{O}_{2}$-treated cells. Co-treatment with PD 098058 and SB 203580 decreased ERK phospho-

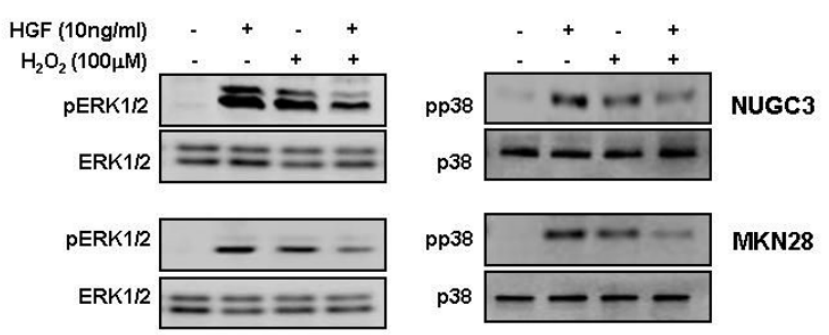

Figure 10

Effects of $\mathrm{H}_{2} \mathrm{O}_{2}$ on ERK and p38 activation induced by HGF. Serum-starved cells were pretreated with or without $\mathrm{H}_{2} \mathrm{O}_{2}(\mathrm{I} 00 \mu \mathrm{M})$ for 30 min and then treated with or without HGF (I $0 \mathrm{ng} / \mathrm{ml})$. After incubation for $15 \mathrm{~min}$, the levels of phosphorylated ERK, ERK, phosphorylated p38, and p38 were measured by Western blot analysis. Representative data from 3 independent experiments are shown. rylation. These results suggested that $\mathrm{H}_{2} \mathrm{O}_{2}$-mediated uPA secretion and the augmentation of this activity were regulated by ERK activation, and p38 activation might indirectly affect $\mathrm{H}_{2} \mathrm{O}_{2}$-mediated uPA secretion. In other words, the increments of $\mathrm{H}_{2} \mathrm{O}_{2}$-mediated uPA secretion and its level of expression according to the treatment by SB 203580 were mediated through ERK activation (Figure 12).

\section{Discussion}

An abundance of evidence indicates the ROS play a central role in the key intracellualar signal transduction pathway for a variety of cellular process $[11,12]$. Aberrant ROS signaling may result in physiologic and pathologic changes, such as cell cycle progression [13], apoptosis, and aging [14]. Previously, elevated oxidative status has been found in many types of cancer cells, which contribute to carcinogenesis [15]. Recently, the involvement of ROS signaling in tumor metastasis was highlighted $[16,17]$. More evidence indicated that metastasis of tumor cells was closely associated with the microenvironment around the primary tumor lesions in which the growth factors and cytokines, such as transforming growth factor- $\beta$ (TGF- $\beta$ ) and HGF, support malignant growth, invasion, and dissemination of the primary tumor [18]. Several important signal transduction pathways, such as MAPK, PI3K, and the Rho-GTPase cascades, are known to mediate transcriptional regulation of metastasis-related genes, such as MMPs [19]. Importantly, ROS are closely associated with these signal cascades, strongly implicating the involvement of ROS in tumor progression.

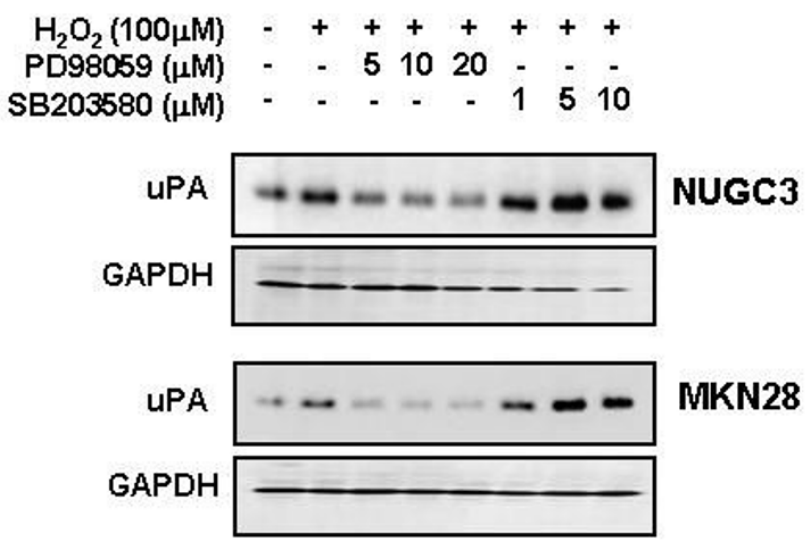

Figure I I

Effects of PD 98059 or SB 203580 on HGF-mediated up-regulation of uPA. Serum-starved cells were pretreated with or without $\mathrm{H}_{2} \mathrm{O}_{2}(\mathrm{I} 00 \mu \mathrm{M})$ for 30 min and then treated with PD 98059 (5, 10 and $20 \mu \mathrm{M})$ or SB 203580 (I, 5 and $10 \mu \mathrm{M})$. After incubation for $24 \mathrm{~h}$, uPA in culture media was measured by Western blot analysis. Representative data from 3 independent experiments were shown. 


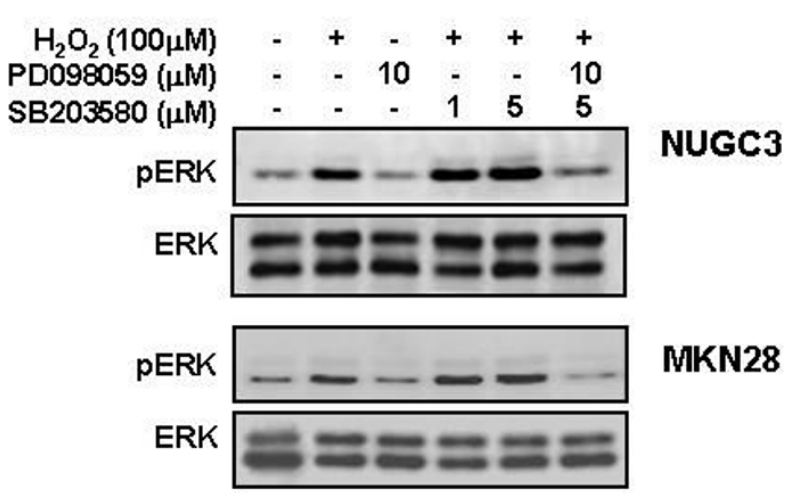

Figure 12

Effects of PD 98059 and/or SB 203580 on $\mathrm{H}_{2} \mathrm{O}_{2}$ induced ERK phosphorylation. Serum-starved cells were pretreated with PD 98059 (I0 $\mu \mathrm{M}$ ) and/or SB 203580 (I and $5 \mu \mathrm{M})$ for $30 \mathrm{~min}$ and then treated with HGF $(10 \mathrm{ng} / \mathrm{ml})$ for I 5 min. ERK activation was evaluated by Western blot analysis. Representative data from 3 independent experiments are shown.

The Rac-1, a small GTPase, is an important regulator of ROS production within cells under hypoxia/re-oxygenation circumstances [20]. Rac-1 belongs to the rho family of small GTP-binding proteins and its role in the production of ROS in phagocytic cells, such as neutrophils, is well-established [21]. In such cells, Rac proteins are essential for the assembly of the plasma membrane NADPH oxidase, which is responsible for the transfer of electrons to molecular oxygen, leading to the production of superoxide anions. Rac-1-regulated ROS have been implicated in a variety of cellular process, including growth, migration, and transformation [22,23].

HGF is a prototypical prosurvival growth factor and also known to prevent non-transformed hepatocytes from oxidant-mediated apoptosis [24]. Ozaki et al. demonstrated that HGF-stimulated activation of pI3K-AKT is necessary and sufficient to suppress intracellular oxidative stress and apoptosis by inhibiting activation of pro-apoptotic, prooxidative Rac-1 GTPase [25]. In our study, we showed HFG decreased Rac-1 protein and ROS production, and intracellular ROS production increased when treated with the PI3-kinase inhibitor, LY294002. Miura et al have already reported that ROS promote rat ascites hepatoma cell invasion beneath mesentery-derived mesothelial cell monolayers. To investigate the mechanisms for this, they examined the involvement of HGF. The rat ascites hepatoma cell line, AH109A, expresses HGF and c-Met mRNAs. Treatment with ROS augments the amount of HGF mRNA in AH109A and the HGF concentration in the medium. ROS also induces HGF gene expression in mesothelial cells. Exogenously-added HGF enhances the inva- sive activity of AH109A cells. Pretreatment with ROS shows increased invasive activity, which is blocked by simultaneous pretreatment with anti-HGF antibody. These results suggest that the invasive activity of AH109A is mediated by autocrine and paracrine pathways of HGF, and ROS potentiate invasive activity by inducing gene expression of HGF in AH109A and mesothelial cells [26]. In our study, $100 \mu \mathrm{M} \mathrm{H}_{2} \mathrm{O}_{2}$ increased HGF gene expression. When we co-treated with exogenous $\mathrm{HGF}$ and $\mathrm{H}_{2} \mathrm{O}_{2}$, it showed downregulation of HGF gene expression.

The overexpression of uPA has been detected in various malignancies, including breast $[27,28]$ and colon cancers [29]. Some dates have shown that a high level of uPA in tumors is associated with a rapid disease progression and a poor prognosis [30,31]. Miyazono et al. [32] showed oxidative stress induces $\mathrm{UPA}$ in RC-K8 human malignant lymphoma cells and $\mathrm{H} 69$ human small cell lung carcinoma cells. Kim et al. reported that ROS precedes the induction of UPAR expression, and this upregulation is attenuated by NAC, a ROS scavenger. In addition, exogenous ROS alone induced the expression and promoter activity of uPA [33]. Our study showed similar results with the above studies. Exogenous $\mathrm{H}_{2} \mathrm{O}_{2}$ increased uPA production and inhibited uPA after treatment of NAC.

Two of the candidate signaling molecules involved in EMT and cell migration are protein kinase C- (PKC) and MAP kinase-mediated signal pathways, which coordinate complex physiologic and pathologic events, including cell cycle control, differentiation, neo-angiogenesis, and metastasis [34]. Cytokines, such as TGF- $\beta$, HGF, and fibroblast growth factor, may stimulate tumor invasion metastasis via PKC and MAP kinase [35]. Mechanisms by which ROS affect signal transduction and gene expression have been described; some works have shown that ROS can activate MAPK, including ERK and p38 kinase. Meanwhile, serine and threonine protein kinase AKT is also regulated by exogenous and endogenous ROS [36,37]. How MAP kinase is activated by ROS to trigger cell migration is not clear. Protein kinase may be activated by ROS for a variety of cellular effects. Moreover, protein kinase is also an upstream kinase of MAPK required for cell migration [38]. Wu et al. [39] found ROS plays a central role in mediating PKC and ERK signaling for regulation of gene expression of integrins and E-cadherin that are responsible for EMT and migration of the human hepatoma cell line, HepG2. Lee et al. [40] examined the role of the MAP kinase signaling pathway on the stimulation of uPA synthesis in gastric cancer cells by using HGF. They showed that the phosphorylation of ERK and p38 kinase are dependent on the dosage of HGF and also clarified that uPA secretion and zymoactivity in the NUGC-3 cell lines were stimulated with HGF, which suggests the involvement of ERK and p38 kinase in the HGF-mediated uPA 


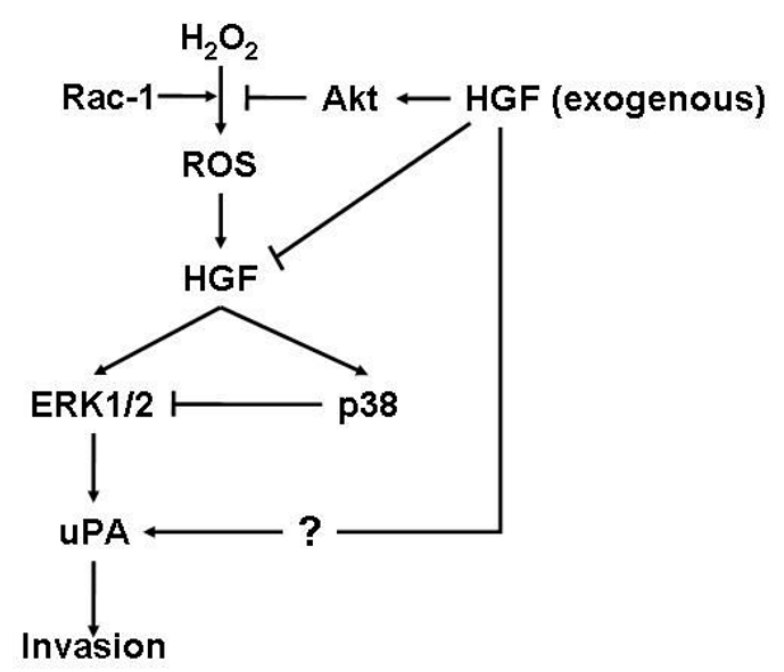

Figure 13

Interaction of exogenous $\mathrm{HGF}$ with $\mathrm{H}_{2} \mathrm{O}_{2}$ in uPA expression.

expression. The effects of PD098059 and SB203580 were measured in order to clarify which signaling pathway, between the ERK and p38 kinase pathways, plays the more important role in $\mathrm{H}_{2} \mathrm{O}_{2}$-induced uPA secretion. Increments of $\mathrm{H}_{2} \mathrm{O}_{2}$-mediated $\mathrm{uPA}$ expression via $\mathrm{SB}$ 203580 pretreatment were shown to be mediated by ERK activation, indicating that p38 kinase functions as a negative growth regulator. Xian et al. [41] also reported similar results in the PCNC-1 pancreatic cancer cell line.

In this study, we showed that HGF decreased intracellular ROS and increased the uPA protein levels. Treatment with $\mathrm{H}_{2} \mathrm{O}_{2}$ also increased HGF mRNA and uPA protein. However, co-treatment with $\mathrm{HGF}$ and $\mathrm{H}_{2} \mathrm{O}_{2}$ decreased uPA, and HGF mRNA and protein levels increased by $\mathrm{H}_{2} \mathrm{O}_{2}$ treatment. These results suggest that exogenous HGF might play a negative role in the regulation of $\mathrm{UPA}$ protein levels increased by $\mathrm{H}_{2} \mathrm{O}_{2}$ treatment (Figure 13). Thus, further study is necessary to elucidate by which mechanism exogenous HGF regulates uPA protein levels through the regulation of intracellular ROS levels and signal pathways.

Overall, these results suggest that ROS are involved uPA regulation in control of tumor invasion and metastasis by cytokines, such as HGF in gastric cancer cells. Notwithstanding the above limitation, evidence that ROS directly contributes to HGF/c-Met-dependant tumor invasion and metastasis opens a novel perspective in the complex correlation between oxygen radicals and malignancy, and suggests new possibilities of antioxidant-based therapeutic intervention, complementary to the search for $\mathrm{HGF} / \mathrm{c}$ Met inhibitory compounds.

\section{Competing interests}

The authors declare that they have no competing interests.

\section{Authors' contributions}

KHL carried out cell treatment, cell transfection, immunoblotting analysis and drafted the manuscript. SWK participated in the design of the study, coordination and performed the statistical analysis. JRK supervised experimental work. All authors read and approved the final manuscript.

\section{Acknowledgements}

This work was supported by the Korea Science and Engineering Foundation (KOSEF) NCRC grant funded by the Korea government (MEST: R I5-2004033-0500I-0), and by the KOSEF MRC grant funded by the MEST (RI32005-005-0100I-0).

\section{References}

I. Halliwell B, Gutteridge JMC: Antioxidant defences. In Free radicals in biology and medicine New York, NY: Oxford University Press; 1999.

2. Janssen AML, Bosman CB, Kruidenier L, Griffioen G, Lamers CBHV, Van Krieken JHIM, Velde CJH Van de, Verspaget HW: Superoxide dismutase in the human colorectal canter sequence. Journal of Cancer Research and Clinical Oncology 1999, I 25:327-335.

3. Bottaro DP, Rubin JS, Faletto DL, Chan AM, Kmiecik TE, Woude GF Vande, Aaronson SA: Identification of the hepatocyte growth factor receptor as the c-met proto-oncogene product. Science |99|, 25 I:802-804.

4. Bowers DC, Fan S, Walter KA, abounader R, Williams JA, Rosen EM, Laterra J: Scatter factor/hepatocyte growth factor protects against cytotoxic death in human glioblastoma via phosphatidylinositol 3-kinase-and AKT-dependent pathways. Cancer Res 2000, 60:4277-4283.

5. Di Renzo MF, Olivero M, Giacomini A, Porte H, Chastre E, Mirossay L, Nordinger B, Bretti S, Bottardi S, Giordano S, Plebano M, Gespach C, Comoglio PM: Overexpression and amplification of the met/ HGF receptor gene during the progression of colorectal cancer. Clin Cancer Res. 1995, I(2): I47-154.

6. Restuccia C, Angeluccl A, Gravlna GL, Villanova I, Teti A, Albini A, Bologna M: Osteoblast-derived TGF-betal modulates matrix degrading protease expression and activity prostate cancer cells. Int J Cancer 2000, 85:407-I 5.

7. Lee KH, Hyun MS, Kim JY: Invasion-Metastasis by Hepatocyte Growth Factor/c-Met Signaling Concomitant with Induction of Urokinase plasminogen Activator in Human Pancreatic Cancer: Role as Therapeutic Target. Cancer Research Treatment 2003, 35:207-12.

8. English J, Pearson G, Wilsbacher J, Swantek J, Karandikar M, Xu S, Cobb MH: New insights into the control of MAP kinase pathways. Exp Cell Res 1999, 253:255-70.

9. Widmann C, Gibson S, Harpe MB, Johnson GL: Mitogen-activated protein kinase: conservation of a three-kinase module from yeast to human. Physiol Rev 1999, 79:|43-80.

10. Gupta A, Rosenberger SF, Bowden GT: Increased ROS levels contribute to elevated transcription factor and MAP kinase activities in malignantly progressed mouse keratinocyte cell lines. Carcinogenesis 1999, 20:2063-2073.

II. Aslan M, Azben T: Oxidants in receptor tyrosine kinase signal transduction pathways. Antioxid Redox Signal. 2003, 5(6):781-788.

12. Chiarugi P: The redox regulation of LMW-PMP during cell proliferation or growth inhibition. IUBMB Life 200I, 52:55-59.

13. Boonstra J, Post JA: Molecular events associated with reactive oxygen species and cell cycle progression in mammalian cells. Gene 2004, 337: I- I3.

14. Gourlay CW, Ayscough KR: The actin cytoskeleton: A key regulator of apoptosis and ageing? Nature Reviews. Molecular Cell Biology 2005, 6:583-589.

15. Toyokumi Winter S: Reactive oxygen species-induced molecular damage and its application in pathology. Pathology International 1999, 49:91-102. 
16. Radisky DC, Levy DD, Littlepage LE, Liu HH, Nelson CM, Fata JE, Leake D, Godden EL, Albertson DG, Nieto MA, Werb Z, Bissell MJ: Rac Ib and reactive oxygen species mediate MMP-3-induced EMT and genomic instability. Nature 2005, 436:123-127.

17. Chambers AF, Groom AC, MacDonald IC: Dissemination and growth of cancer cells in metastatic sites. Nature Reviews. Cancer 2002, 2:563-572.

18. Kassis J, Klominek J, Kohn EC: Tumor microenvironment: What can ffusions teach us? Diagnostic Cytopathology 2005, 33:316-319.

19. Melson KK, Melendez JA: Mitochondrial redox control of matrix metalloproteinases. Free Radical Biology \& Medicine 2004, 37:768-784.

20. Ozaki Deshpande SS, Angkow P, Bellan J, Lowenstein CJ, Dinauer MC, Goldschmidt Clermont PJ, Irani K: Inhibition of the Racl GTPase protects against nonlethal ischemia/reperfusion-induced necrosis and apoptosis in vivo. FASEB J 2000, I4:418-429.

21. Faris SL, Rinckel LA, Huang J, Hong YR, Kleinberg ME: Phagocyte NADPH oxidase p67-phox possesses a novel carboxyl terminal binding site for the GTPases Rac 2 and Cdc42. Biochem Biophys Res Commun 1998, 247:27I-276.

22. Yeh LH, Park YJ, Hansalia RJ, Ahmed IS, Deshpande SS, Goldschmidt Clemont PJ, Irani K, Alevriadou BR: Shear-induced tyrosine phosphorylation in endothelial cells requires Racl-dependent production of ROS. AM J Physiol 1999, 276:C838-C847.

23. Wang Z, Castresana MR, Newman WH: Reactive oxygen and NFkappa $B$ in VEGF-induced migration of human vascular smooth muscle cells. Biochem Biophys Res Commun 200I, 285:669-674.

24. Kosai K, Matsumoto K, Funakoshi H, Nakamura T: Hepatocyte growth factor prevents endotoxin-induced lethal hepatic failure in mice. Hepatology 1999, 30:151-159.

25. Ozaki M, Haga S, Zhang HG, Irani K, Suzuki S: Inhibitions of hypoxia/reoxygenation-induced oxidative stress in HGFstimulated anti-apoptotic signaling: role of PI3-K and Akt kinase upon racl. Cell Death and Differentiation 2003, I0:508-5I5.

26. Miura $Y$, Kozuki $Y$, Yagasaki K: Potentiation of invasive activity of hepatoma cells by reactive oxygen species is mediated by autocrine/paracrine loop of hepatocyte growth factor. Biochem Biophys Res Commun 2003, 305:160-165.

27. Xing RH, Rabbani SA: Overexpression of urokinase receptor in breast cancer cells result in increased tumor invasion, growth and metastasis. Int / Cancer 1996, 67:423-9.

28. Duggan C, Maguire T, McDermott E, O'Higgins N, Fennelly JJ, Duffy MJ: Urokinase plasminogen activator and urokinase plasminogen activator receptor in breast cancer. Int J Cancer 1995 , 6I:597-600.

29. Yang JL, Seetoo DG, Wang Y, Ranson M, Bemey CR, Ham JM, Russell PJ, Crowe PJ: Urokinase-type plasminogen activator and its receptor in colorectal cancer: independent prognostic factors of metastasis and cancer-specific survival and potential therapeutic targets. Int / Cancer 2000, 20:43I-9.

30. Solomayer EF, Kiel IJ, Wallwlener D, Bode S, Meyberg G, Sillem M, Gollan $\mathrm{CH}$, Kramer MD, Krainick U, Baster G: Prognostic relevance of urokinase plasminogen activator detection in micrometastatic cells in the bone marrow of patients with primary breast cancer. Br J Cancer 1997, 76:8I2-8.

3I. Bouchetm C, Spyratos F, Hacène K, Furcos L, Bécette V, Oglobine J: Prognostic value of urokinase plasminogen activator in primary breast carcinoma: comparison of two immunoassay methods. Br J Cancer 1998, 77(9): I495-50I.

32. Miyazono T, Niiya K, Kiguchi T, Sakuragawa N, Harada M, Watanabe $\mathrm{A}$ : Oxidative stress induces urokinase-type plasminogen activator in RC-K8 human malignant lymphoma cells and H69 human small cell lung carcinoma cells. Fibrinolysis Proteolysis 2000, 14:366-73.

33. Kim MH, Yoo HS, Kim MY, Jang HJ, Baek MK, Kim HR, Kim KK, Shin BA, Ahn BW, Jung YD: Helicobacter pylori stimulates urokinase plasminogen activator receptor expression and cell invasiveness through reactive oxygen species and NF-kB signaling in human gastric carcinoma cells. Int I Mol Med 2007 , 19(4):689-697.

34. Hofmann J: Protein kinase $\mathbf{C}$ isohyets as potential targets for anticancer therapy. Curr Cancer Drug Targets 2004, 4: 125-46.

35. Lee KH, Hyun MS, Kim JR: Growth factor-dependent activation of the MAPK pathway in human pancreatic cancer: MEK/
ERK and p38 MAP kinase interactionin uPA synthesis. Clin Exp Metastasis 2003, 20:499-505.

36. Gupta A, Rosenberger SF, Bowden GT: Increased ROS levels contribute to elevated transcription factor and MAP kinase activities in malignantly progressed mouse keratinocyte cell lines. Carcinogenesis 1999, 20:2063-2073.

37. Klotz LO, Pellieux C, Briviba K, Pierlot C, Aubry JM, Sies H Mitogen-activated protein kinase (p38-, JNK-, ERK-) activation pattern induced by extracellular and intracellular singlet oxygen and UVA. Eur J Biochem 1999, 260:917-922.

38. Kenmorgant S, Zicha D, Parker PJ: PKC controls HGF-dependent c-Met traffic, signaling and cell migration. EMBO Journal 2004, 23:372I-3734.

39. Wu W-S, Tsai RK, Chang CH, Wang S, Wu J-R, Chang Y-X: Reactive Oxygen Species Mediated Sustained Activation of Protein Kinase $C$ and Extracellular Signal-Regulated Kinase for Migration of Human Hepatoma Cell HepG2. Mol Cancer Res 2006, 4(I0):747-58.

40. Lee KH, Choi EY, Kim MK, Hyun MS, Jang BI, Kim TN, Kim SW, Song SK, kim JH, Kim J-R: Regulation of hepatocyte growth factormediated urokinase plasminogen activator secretion by MEK/ERK activation in human stomach cancer cell lines. Exp Mol Med 2006, 38(I):27-35.

4I. Xian ZD, Thomas EA: MEK/ERK-mediated proliferation is negatively regulated by $P 38$ MAP kinase in the human pancreatic cancer cell line, PANC-I. Biochem Biophy Res Commun 200I, 282:447-53.
Publish with Biomed Central and every scientist can read your work free of charge

"BioMed Central will be the most significant development for disseminating the results of biomedical research in our lifetime. "

Sir Paul Nurse, Cancer Research UK

Your research papers will be:

- available free of charge to the entire biomedical community

- peer reviewed and published immediately upon acceptance

- cited in PubMed and archived on PubMed Central

-yours - you keep the copyright 